\title{
Longitudinal Observation on the Chest Circumference and Sitting Height of Japanese-American Hybrids from 6 to 15 Years of Age
}

\author{
Akiyoshi Suda ${ }^{1}$, Hiroshi Hoshi' ${ }^{2)}$, Masahiko SAto ${ }^{3)}$, \\ Moriharu Eтo ${ }^{4)}$ and Kumi Ashizawa ${ }^{5)}$
}

This is the second report on the somatometrical part of the longitudinal growth study on Japanese-American hybrids. Mean growth trends of the stature and body weight of the same sample were reported in 1965. Longitudinal data obtained from 36 male and 21 female hybrids were analysed in this report. According to their fathers' racial characteristics, these hybrids were divided into two groups: Those whose farthers were American whites and those whose fathers were American negroes, which were called "white hybrids" and "negro hybrids" respectively for short. Each subject undressed was measured for the chest circumference and sitting height repeatedly at intervals of 6 months by using a steel tape and anthropometer. Mean values were compared between the hybrids and the school children in Tokyo born in 1947. Data on the latter were quoted from the reports annually published by the Japanese Ministry of Education. Unfortunately, no data on the white children comparable with those studied in the present research were available, and the present analysis was limited to comparison with the native Japanese.

\section{CHEST CIRCUMFERENCE}

As to mean values, there is no difference between the white and negro hybrids regardless of age or sex. In males, the hybrids are significantly greater than the Japanese after 14 years of age (Fig. 1, Table 1). This finding is essentially the same as that obtained in the case of stature and body weight. In females, however, the negro hybrids showed a marked growth acceleration and surpassed the Japanese to a large extent after 9 years of age, while the white hybrids presented the same acceleration after 12 years of age. The considerably better development of the breasts (mammae) in the hybrid girls may be responsible for the very difference between the hybrids and the Japanese. From these findings, it was coucluded that hereditary influence might first appear at adolescence in the chest circumference as well as in the stature and body weight.

In age trend of annual increments of the chest circumference, there were

This work was supported by the Ministry of Education, Japan and partly by the JIBP. 

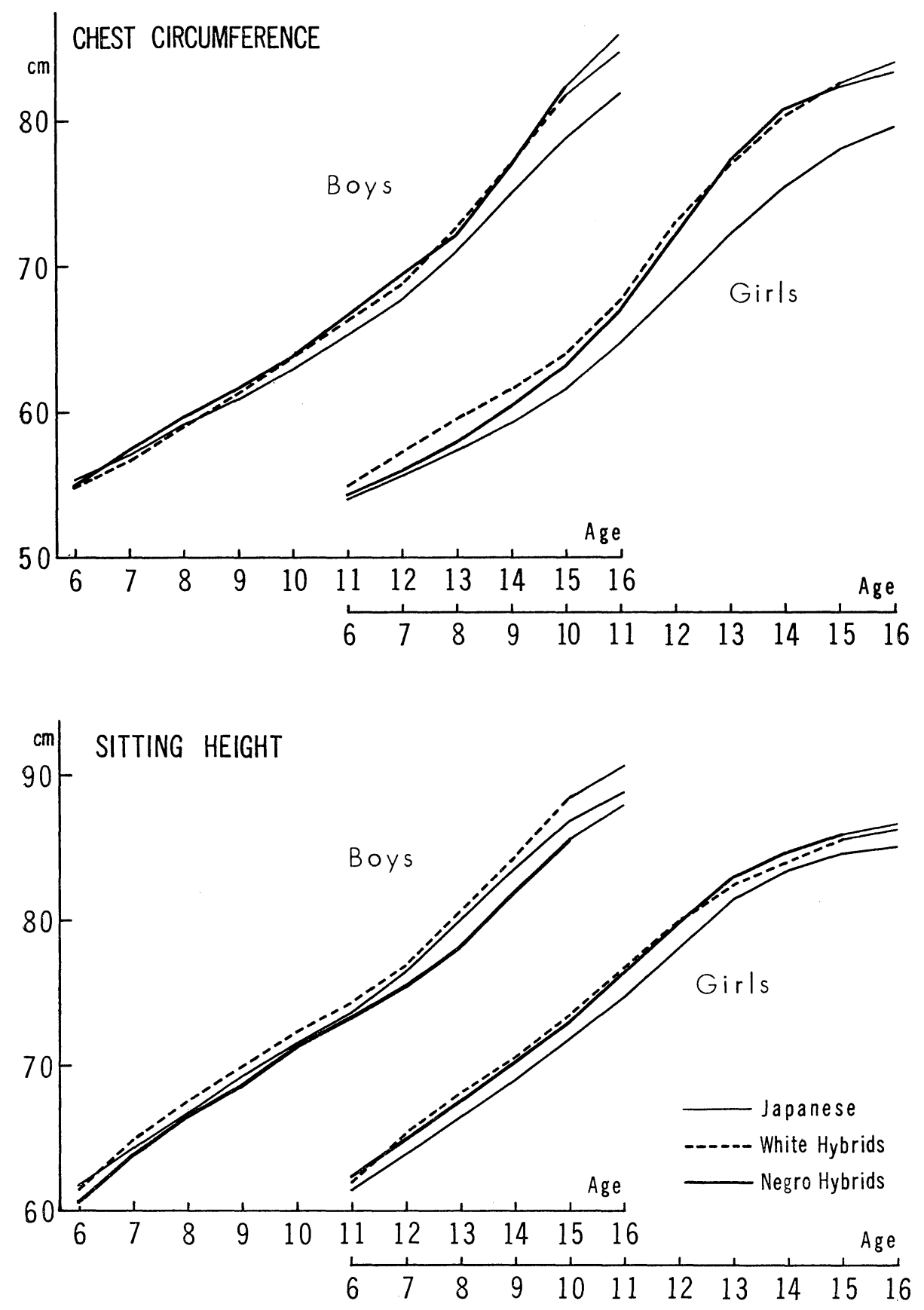

Fig. 1. Mean growth curves of the chest circumference and sitting height in Japanese-American hybrids and native Japanese. 


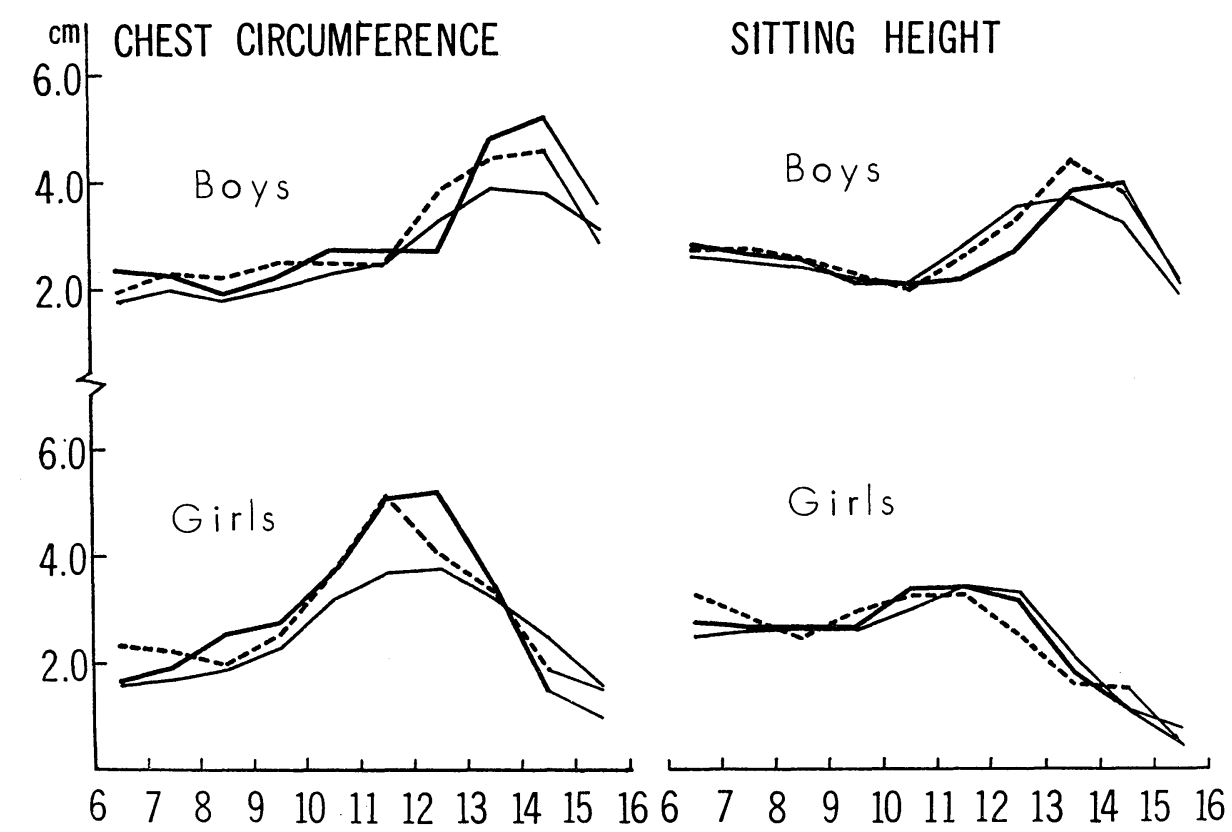

Fig. 2. Mean velocity curves of the chest circumference and sitting height in Japanese-American hybrids and native Japanese.

noticeable differences between sexes (Fig. 2). In females, the age curve of the negro hybrids showed fluctuation almost parallel to that of the Japanese, while the curve of the white hybrids reached its peak a little earlier than that of any other group. In males, on the contrary, the curve of the hybrids reached its peak just or more than one year later than that of the Japanese. In both sexes, it must be noted that the annual gain at peak was markedly greater in the hybrids than in the Japanese. This last finding is the same as that obtained from the analysis of stature and body weight (SUDA et al. 1965).

\section{SITTING HEIGHT}

Analysis of mean values has revealed that the difference between the white and negro hybrids is negligible in females, but is not so in males (Fig. 1, Table 1). During the prepuberal period, the mean values for male hybrids were practically the same as those of the Japanese. When puberty was reached, the negro male hybrids began to show accelerated growth at a fairly later age period as compared with any other group. Therefore after the puberal period, the sitting height was lower in the negro hybrids than in the Japanese or the white hybrids. The difference between the negro and white hybrids was significant as the ages of $12,13,14$ and 15 years (at $5 \%$ level). It seems highly possible that this difference between the negro and white hybrids may have been brought about 
by the different hereditary composition which was potentially adopted to them by their respective parents and which gave rise to distinct type of physique through the period of adolescence.

Female hybrids seem to be larger than the Japanese throught the ages studied, but the differece between them is not significant at any age. It is of great interest to note that the curves for the three groups are strikingly parallel to one another throughut the age span studied.

As for annual increments, the white male hybrids reached the maximum velocity about one year later than the Japanese did. The same was commonly

Table 1. Mean values and annual increments of the chest circumference and sitting height in Japanese-American hybrids and native Japanese. Statistical significance against native Japanese is shown by one or two asterisks ( $5 \%$ or $1 \%$ level).

A. Chest Circumference in Males (cm)

\begin{tabular}{|c|c|c|c|c|c|c|c|c|c|c|c|c|}
\hline \multirow{2}{*}{ Age } & \multicolumn{4}{|c|}{ White Hybrids } & \multicolumn{4}{|c|}{ Negro Hybrids } & \multicolumn{4}{|c|}{ Japanese } \\
\hline & $\mathrm{N}$ & $\bar{x}$ & $\mathrm{u}$ & Inc. & $\mathrm{N}$ & $\bar{x}$ & $\mathrm{u}$ & Inc. & $\mathrm{N}$ & $\bar{x}$ & SD & Inc. \\
\hline 6 & 25 & 54.80 & 1.72 & \multirow{11}{*}{$\begin{array}{l}1.92 \\
2.29 \\
2.22 \\
2.51 \\
2.49 \\
2.48 \\
3.85 \\
4.51 \\
4.60 \\
2.96\end{array}$} & 11 & 54.92 & 2.07 & \multirow{11}{*}{$\begin{array}{l}2.39 \\
2.28 \\
1.93 \\
2.23 \\
2.78 \\
2.76 \\
2.72 \\
4.92 \\
5.26 \\
3.62\end{array}$} & 5852 & 55.3 & 2.4 & \multirow{7}{*}{$\begin{array}{l}1.8 \\
2.0 \\
1.8 \\
2.0 \\
2.3 \\
2.5\end{array}$} \\
\hline 7 & 25 & 56.72 & 1.77 & & 11 & 57.33 & 1.96 & & 6274 & 57.1 & 2.5 & \\
\hline 8 & 25 & 59.01 & 2.13 & & 11 & 59.61 & 2.07 & & 2428 & 59.1 & 2.7 & \\
\hline 9 & 25 & 61.23 & 2.22 & & 11 & 61.54 & 2.08 & & 2468 & 60.9 & 2.9 & \\
\hline 10 & 25 & 63.74 & 2.20 & & 11 & 63.77 & 2.04 & & 2380 & 62.9 & 3.0 & \\
\hline 11 & 25 & 66.23 & 2.25 & & 11 & 66.55 & 2. 62 & & 2690 & 65.2 & 3.7 & \\
\hline 12 & 25 & 68.71 & 2.11 & & 11 & 69.31 & 2.17 & & 6210 & 67.7 & 4.7 & \\
\hline 13 & 25 & 72.56 & 3. 27 & & 11 & 72.03 & 2.53 & & 6407 & 71.0 & 5.3 & \\
\hline 14 & 25 & $77.07^{*}$ & 3.54 & & 11 & 76.95 & 3. 41 & & 6543 & 74.9 & 5.4 & \\
\hline 15 & 25 & $81.67^{* *}$ & 3. 48 & & 11 & $82.21^{*}$ & 3.98 & & 7347 & 78.7 & 5.0 & 3.8 \\
\hline 16 & 16 & $84.63^{*}$ & 2.61 & & 7 & $85.83^{*}$ & 3.89 & & 6341 & 81.8 & 4.9 & 3.1 \\
\hline
\end{tabular}

B. Chest Circumference in Females (cm)

\begin{tabular}{|c|c|c|c|c|c|c|c|c|c|c|c|c|}
\hline \multirow{2}{*}{ Age } & \multicolumn{4}{|c|}{ White Hybrids } & \multicolumn{4}{|c|}{ Negro Hybrids } & \multicolumn{4}{|c|}{ Japanese } \\
\hline & $\mathrm{N}$ & $\bar{x}$ & $\mathbf{u}$ & Inc. & $\mathrm{N}$ & $\bar{x}$ & $\mathrm{u}$ & Inc. & $\mathrm{N}$ & $\bar{x}$ & $\mathrm{SD}$ & Inc. \\
\hline 6 & 11 & 54.92 & 2.30 & \multirow{4}{*}{$\begin{array}{l}2.32 \\
2.22 \\
1.95\end{array}$} & 10 & 54.24 & 1.28 & \multirow{3}{*}{$\begin{array}{l}1.67 \\
1.91\end{array}$} & 5579 & 54.0 & 2.4 & \multirow{2}{*}{1.6} \\
\hline 7 & 11 & $57.24^{* *}$ & 2.86 & & 10 & 55.91 & 1.51 & & 6019 & 55.6 & 2.4 & \\
\hline 8 & 11 & $59.51^{* *}$ & 2.40 & & 10 & 57.82 & 1. 64 & & 2285 & 57.3 & 2.9 & \\
\hline 9 & 11 & $61.46^{* *}$ & 2.97 & & 10 & $60.38 *$ & 1. 41 & \multirow{3}{*}{$\begin{array}{l}2.78 \\
3.70\end{array}$} & 2248 & 59.2 & 3.2 & \multirow{2}{*}{2.3} \\
\hline 10 & 11 & $63.98 * *$ & 4. 12 & \multirow{2}{*}{$\begin{array}{l}2.52 \\
3.70\end{array}$} & 10 & $63.16^{*}$ & 1.58 & & 2337 & 61.5 & 3.7 & \\
\hline 11 & 11 & $67.68^{* *}$ & 4.87 & & 10 & $66.86^{*}$ & 1.96 & & 2482 & 64.7 & 4.6 & \\
\hline 12 & 11 & $72.85^{* *}$ & 7.00 & \multirow{5}{*}{$\begin{array}{l}4.08 \\
3.34 \\
1.90 \\
1.51\end{array}$} & 10 & $71.96^{*}$ & 2.59 & \multirow{5}{*}{$\begin{array}{l}5.10 \\
5.21 \\
3.57 \\
1.50 \\
1.01\end{array}$} & 5110 & 68.4 & 5.1 & \multirow{5}{*}{$\begin{array}{l}3.7 \\
3.8 \\
3.2 \\
2.5 \\
1.9\end{array}$} \\
\hline 13 & 11 & $76.93 * *$ & 7.02 & & 10 & $77.17^{* *}$ & 2.73 & & 5754 & 72.2 & 5.1 & \\
\hline 14 & 11 & $80.27 * *$ & 6.14 & & 10 & $80.74 * *$ & 1.92 & & 5911 & 75.4 & 4.9 & \\
\hline 15 & 11 & $82.37^{* *}$ & 4.96 & & 10 & $82.24 * *$ & 2.03 & & 6731 & 77.9 & 4.7 & \\
\hline 16 & 8 & $83.88 * *$ & 4.24 & & 6 & $83.25^{*}$ & 2.89 & & 7634 & 79.5 & 4.5 & \\
\hline
\end{tabular}


C. Sitting Height in Males (cm)

\begin{tabular}{|c|c|c|c|c|c|c|c|c|c|c|c|c|}
\hline \multirow{2}{*}{ Age } & \multicolumn{4}{|c|}{ White Hybrids } & \multicolumn{4}{|c|}{ Negro Hybrids } & \multicolumn{4}{|c|}{ Japanese } \\
\hline & $\mathrm{N}$ & $\bar{x}$ & $\mathrm{u}$ & Inc. & $\mathrm{N}$ & $\bar{x}$ & $\mathrm{u}$ & Inc. & $\mathrm{N}$ & $\bar{x}$ & SD & Inc. \\
\hline 6 & 25 & 62.01 & 1.88 & & 11 & 61.12 & 2.57 & & 5851 & 61.8 & 2.6 & \\
\hline 7 & 25 & 64.74 & 1.69 & $\begin{array}{l}2.13 \\
272\end{array}$ & 11 & 63.94 & 1.67 & $\begin{array}{l}2.82 \\
2.67\end{array}$ & 6280 & 64.4 & 2.7 & 2.6 \\
\hline 8 & 25 & 67.47 & 1.66 & & 11 & 66.61 & 1.33 & & 2427 & 66.9 & 2.8 & 2.5 \\
\hline 9 & 25 & $70.02 *$ & 1.52 & 2.55 & 11 & 69.15 & 1.13 & $\begin{array}{l}2.54 \\
2.10\end{array}$ & 2468 & 69.3 & 2.8 & 2.4 \\
\hline 10 & 25 & $72.26^{*}$ & 1. 47 & $\begin{array}{l}2.24 \\
1.99\end{array}$ & 11 & 71.27 & 1. 48 & 2. 12 & 2378 & 71.5 & 2.8 & 2.2 \\
\hline 11 & 25 & 74.25 & 1.56 & 1.99 & 11 & 73. 29 & 1.43 & 2.02 & 2691 & 73.6 & 3.1 & 2.1 \\
\hline 12 & 25 & 76.81 & 1.54 & $\begin{array}{l}2.50 \\
3.24\end{array}$ & 11 & 75.46 & 1.44 & & 6210 & 76.4 & 3.8 & 2.8 \\
\hline 13 & 25 & 80.05 & 2.45 & & 11 & $78.15^{*}$ & 2.26 & & 6409 & 79.9 & 4.5 & 3.5 \\
\hline 14 & 25 & 84.42 & 3. 24 & & 11 & 81.90 & 3.00 & 3.75 & 6521 & 83.6 & 4.2 & 3.7 \\
\hline 15 & 25 & 88.20 & 3.00 & 3.78 & 11 & 85.85 & 2.30 & 3. 95 & 7176 & 86.8 & 3.9 & 3.2 \\
\hline 16 & 16 & 90.39 & 2.79 & 2.19 & 7 & 87.96 & 3. 02 & 2.11 & 6341 & 88.7 & 3.4 & 1.9 \\
\hline
\end{tabular}

D. Sitting Height in Females (cm)

\begin{tabular}{|c|c|c|c|c|c|c|c|c|c|c|c|c|}
\hline \multirow{2}{*}{ Age } & \multicolumn{4}{|c|}{ White Hybrids } & \multicolumn{4}{|c|}{ Negro Hybrids } & \multicolumn{4}{|c|}{ Japanese } \\
\hline & $\mathrm{N}$ & $\bar{x}$ & $\mathrm{u}$ & Inc. & $\mathrm{N}$ & $\bar{x}$ & $\mathrm{u}$ & Inc. & $\mathrm{N}$ & $\bar{x}^{\bullet}$ & SD & Inc. \\
\hline 6 & 11 & 61.96 & 2.44 & & 10 & 62.24 & 3.08 & & 5554 & 61.4 & 2.6 & \\
\hline 7 & 11 & 65.24 & 2.25 & & 10 & 64.97 & 3.03 & & 6025 & 63.9 & 2.6 & \\
\hline 8 & 11 & 68.05 & 2.39 & & 10 & 67.64 & 3. 12 & & 2285 & 66.5 & 2.8 & 2.0 \\
\hline 9 & 11 & 70.48 & 2.23 & 2.43 & 10 & 70.29 & 3.15 & bb & 2248 & 69.1 & 3.0 & 2.6 \\
\hline 10 & 11 & 73. 42 & 2.29 & & 10 & 72.97 & 3.10 & & 2337 & 71.7 & 3.3 & 2.6 \\
\hline 11 & 11 & 76.65 & 2.86 & & 10 & 76.30 & 3.40 & & 2482 & 74.7 & 3.7 & 3 \\
\hline 12 & 11 & 79.90 & 3.50 & & 10 & 79.69 & 2.99 & & 5110 & 78.1 & 3.8 & 0.4 \\
\hline 13 & 11 & 82. 42 & 3.57 & 2.52 & 10 & 82.85 & 3.08 & 3.16 & 5754 & 81.4 & 3.3 & 3.3 \\
\hline 14 & 11 & 84.03 & 3. 07 & 1.01 & 10 & 84.70 & 2. 40 & 1.85 & 5895 & 83.5 & 3.1 & 2.1 \\
\hline 15 & 11 & 85.53 & 3.11 & & 10 & 85.84 & 2.52 & 1.14 & 6738 & 84.6 & 2.7 & 1.1 \\
\hline 16 & 6 & 86.02 & 1.74 & & 6 & 86.63 & 2.95 & 0.13 & 7634 & 85.1 & 2.7 & 0.5 \\
\hline
\end{tabular}

seen in the stature, body weight and chest circumference. The negro female hybrids reached the maximum velocity about one year earlier than the Japanese did. In other points of view, the three groups practically coincided with one another. It must be noted that the maximum annual gain in sitting height was not greater in the hybrids than in the Japanese, in contrast to the fact that the maximum gain was markedly greater in the hybrids than in the Japanese in cases of the stature, body weight and chest circumference. This discordance may be ascribable in part to a fact that the sitting height is one of the parts of the boty or one component of the stature, while any other item of measurement represents the gross size of an organism as a whole from different points of view. 

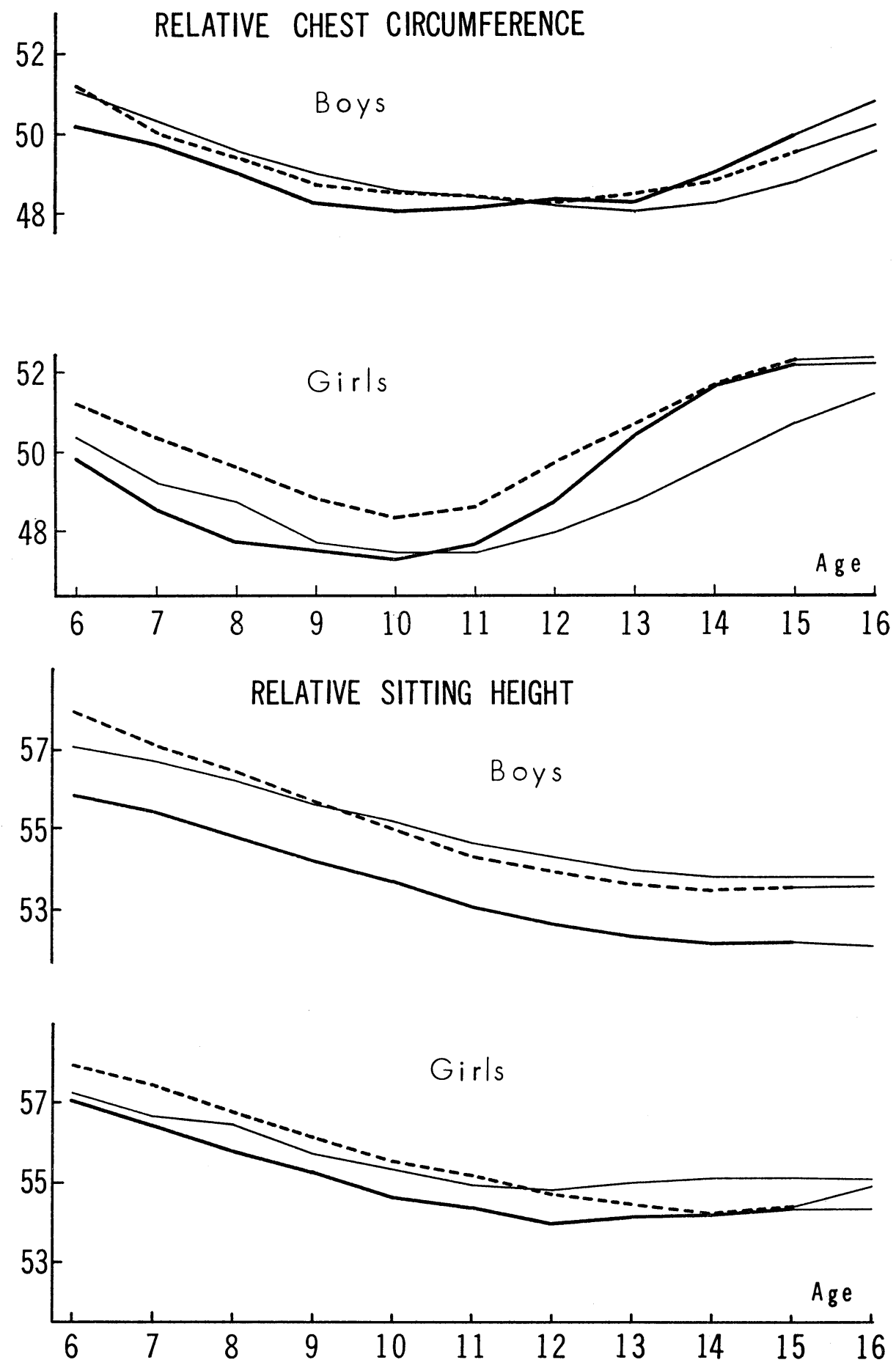

Fig. 3. Mean age trends of the relative chest circumference and sitting height in Japanese-American hybrids and native Japanese. 
Table 2. Mean values of the relative chest circumference and relative sitting height in Japanese-American hybrids and native Japanese.

A. Values for Males

\begin{tabular}{|c|c|c|c|c|c|c|c|c|c|c|c|c|c|c|}
\hline \multirow{3}{*}{ Age } & \multicolumn{7}{|c|}{ Relative Chest Circumference } & \multicolumn{7}{|c|}{ Relative Sitting Height } \\
\hline & \multicolumn{3}{|c|}{ White Hybrids } & \multicolumn{3}{|c|}{ Negro Hybrids } & \multirow{2}{*}{$\begin{array}{c}\text { Japa- } \\
\text { nese } \\
\bar{x}\end{array}$} & \multicolumn{3}{|c|}{ White Hybrids } & \multicolumn{3}{|c|}{ Negro Hybrids } & \multirow{2}{*}{$\begin{array}{c}\text { Japa- } \\
\text { nese } \\
\vec{x}\end{array}$} \\
\hline & $\mathrm{N}$ & $\bar{x}$ & $\mathrm{u}$ & $\mathrm{N}$ & $\vec{x}$ & $\mathrm{u}$ & & $\mathrm{N}$ & $\bar{x}$ & $\mathbf{u}$ & $\mathbf{N}$ & $\bar{x}$ & $\mathbf{u}$ & \\
\hline 6 & 25 & 51.22 & 2.34 & 11 & 50.20 & 2.34 & 51.06 & 25 & 57.92 & 1.81 & 11 & 55.82 & 1.67 & 57.08 \\
\hline 7 & 25 & 50.03 & 2.07 & 11 & 49.73 & 1.60 & 50.31 & 25 & 57.13 & 1.37 & 11 & 55.46 & 1.02 & 56.75 \\
\hline 8 & 25 & 49.42 & 2.07 & 11 & 49.05 & 1.60 & 49.58 & 25 & 56.48 & 1.00 & 11 & 54.81 & 1.03 & 56.23 \\
\hline 9 & 25 & 48.73 & 2.12 & 11 & 48.25 & 1.80 & 49.00 & 25 & 55.70 & 0.90 & 11 & 54.21 & 0.85 & 55.65 \\
\hline 10 & 25 & 48.53 & 1.95 & 11 & 48.05 & 1.80 & 48.57 & 25 & 55.00 & 0.98 & 11 & 53.68 & 0.67 & 55.22 \\
\hline 11 & 25 & 48.42 & 1.80 & 11 & 48.17 & 2. 12 & 48.40 & 25 & 54.27 & 1.05 & 11 & 53.03 & 0.75 & 54.65 \\
\hline 12 & 25 & 48.25 & 1.68 & 11 & 48.33 & 2.00 & 48. 19 & 25 & 53.93 & 1.06 & 11 & 52.61 & 0.84 & 54.30 \\
\hline 13 & 25 & 48.52 & 2.00 & 11 & 48.29 & 1.84 & 48.04 & 25 & 53.58 & 0.88 & 11 & 52.27 & 0.85 & 53.98 \\
\hline 14 & 25 & 48.81 & 1.78 & 11 & 49.01 & 2.12 & 48.29 & 25 & 53.45 & 1.05 & 11 & 52.14 & 0.79 & 53.80 \\
\hline 15 & 25 & 49.55 & 1.79 & 11 & 49.96 & 2.10 & 48.82 & 25 & 53.50 & 1.11 & 11 & 52.17 & 0.61 & 53.80 \\
\hline 16 & 16 & 50.23 & 1.77 & 7 & 50.82 & 1.35 & 49.58 & 16 & 53.53 & 1.10 & 7 & 52.06 & 0.96 & 53.78 \\
\hline
\end{tabular}

B. Values for Females

\begin{tabular}{|c|c|c|c|c|c|c|c|c|c|c|c|c|c|c|}
\hline \multirow{3}{*}{ Age } & \multicolumn{7}{|c|}{ Relative Chest Circumference } & \multicolumn{7}{|c|}{ Relative Sitting Height } \\
\hline & \multicolumn{3}{|c|}{ White Hybrids } & \multicolumn{3}{|c|}{ Negro Hybrids } & \multirow{2}{*}{$\begin{array}{c}\text { Japa- } \\
\text { nese } \\
\bar{x}\end{array}$} & \multicolumn{3}{|c|}{ White Hybrids } & \multicolumn{3}{|c|}{ Negro Hybrids } & \multirow{2}{*}{$\begin{array}{c}\text { Japa- } \\
\text { nese } \\
\bar{x}\end{array}$} \\
\hline & $\mathrm{N}$ & $\bar{x}$ & $\mathbf{u}$ & $\mathrm{N}$ & $\bar{x}$ & $\mathbf{u}$ & & $\mathrm{N}$ & $\bar{x}$ & $\mathbf{u}$ & $\mathrm{N}$ & $\bar{x}$ & $\mathrm{u}$ & \\
\hline 6 & 11 & 51.21 & 1.36 & 10 & 49.81 & 2.30 & 50.37 & 11 & 57.83 & 2.94 & 10 & 57.08 & 1.98 & 57.28 \\
\hline 7 & 11 & 50.36 & 0.90 & 10 & 48.55 & 2.05 & 49.25 & 11 & 57.46 & 2.16 & 10 & 56.36 & 1.73 & 56.70 \\
\hline 8 & 11 & 49.62 & 0.73 & 10 & 47.74 & 1.55 & 48.77 & 11 & 56.79 & 1.63 & 10 & 55.81 & 1. 38 & 56.50 \\
\hline 9 & 11 & 48.87 & 1.09 & 10 & 47.51 & 1. 61 & 47.74 & 11 & 56.09 & 1. 61 & 10 & 55.25 & 1.19 & 55.73 \\
\hline 10 & 11 & 48. 37 & 1.70 & 10 & 47.31 & 1.60 & 47.49 & 11 & 55.57 & 1.68 & 10 & 54.61 & 1.08 & 55.35 \\
\hline 11 & 11 & 48.63 & 1. 61 & 10 & 47.70 & 1.82 & 47.50 & 11 & 55.17 & 1.53 & 10 & 54. 35 & 1. 14 & 54.94 \\
\hline 12 & 11 & 49.75 & 2.50 & 10 & 48.74 & 1.93 & 48.00 & 11 & 54.70 & 1. 20 & 10 & 53.95 & 1. 14 & 54.81 \\
\hline 13 & 11 & 50.73 & 2.74 & 10 & 50.42 & 2.22 & 48.78 & 11 & 54.44 & 1.02 & 10 & 54.11 & 1.73 & 55.00 \\
\hline 14 & 11 & 51.72 & 2.80 & 10 & 51.71 & 2. 17 & 49.77 & 11 & 54.21 & 1. 20 & 10 & 54.21 & 1. 41 & 55.12 \\
\hline 15 & 11 & 52.34 & 2.54 & 10 & 52.20 & 2. 31 & 50.75 & 11 & 54.37 & 1. 28 & 10 & 54.44 & 1. 18 & 55.10 \\
\hline 16 & 8 & 52.40 & 2. 44 & 6 & 52.24 & 1.74 & 51.49 & 4 & 54.91 & 0.61 & 6 & 54.35 & 1. 21 & 55.05 \\
\hline
\end{tabular}

\section{SIZE RELATIVE TO STATURE}

The values of the relative chest circumference decreased with advancing age during the prepuberal period, and then showed an increase at adolescence (Fig. 3 , Table 2). In males, there was no significant difference between the negro and white hybrids throughout the age span studied. It is probably not untill 14 years of age that the values of the hybrids exceeded those of the Japanese significantly.

In females, however, three groups of children took a course of growth more 
or less different from one another. The pattern of age changes in the white hybrids was essentially the same as in the Japanese before 11 years of age, although index values were always greater in the hybrids. After this age, values began to increase rapidly in the white hybrids with advancing age. The difference between the hybrids and Japanese became far more marked after 12 years of age.

On the other hand, the negro female hybrids took a dramatical course of change with age: They were the smallest during the prepuberal period and then showed a marvellously rapid increase at adolescence, reaching almost the same level as the white hybrids. Thus there was a marked difference in the pattern of age change between the negro hybrids and any of the other groups. The negro male hybrids also presented a somewhat similar trend to that of the negro female ones, though their particularity was less distinct.

The relative sitting height decreased with advancing age during the prepuberal period and then increased slightly at adolescence (Fig. 3, Table 2). This trend was recognized only in females. It is probably after 16 years of age that the males may show an increase in value again.

It is of great interest to note that there was a marked difference between the white male hybrids and the negro male hybrids. The difference between them was statistically significant (5\% level) at every age studied. As mentioned above, the hereditary factors are considered most responsible for this marked smallness of the relative sitting height in the negro male hybrids. It must be noted, however, that this smallness appeared first at the adolescent period in the case of the absolute sitting height, whereas it was recognized clearly at 6 years of age in the case of the relative sittting height.

It is worth noting that the curve of the Japanese takes so oblique course as to cross the curve of the white hybrids both in males and females. This difference in pattern of age change between the hybrids and Japanese is limited to the prepuberal stage. At adolescence, the white female hybrids take a particular course of change: The curves of the negro hybrids and Japanese cease to decline at 12 years of age and then begin to rise, while the curve of the white hybrids continues to decline till 14 years of age. The reason of this discordance is unknown.

\section{SUMMARY}

The present longitudinal growth study was made on 36 male and 21 female Japanese-American hybrids to clarify age changes in mean values of the chest circumference and sitting height. Analysis was also made on age changes in size relative to stature in the same subjects. 
(i) In females, the chest circumference was greater in the hybrids than in the Japanese after puberty, probably because of the considerably better development of the breasts (mammae) in the hybrid girls. In males, there was a significant difference between the hybrids and Japanese only after 14 years of age.

(2) As to the sitting height, the male negro hybrids were about one year behind in getting into an adolescent spurt, so that they were the smallest when they reached 12 years of age.

(3) For the relative chest circumference, the female hybrids became greater rapidly than the female Japanese after 10 years of age. In male hybrids, the same rush of growth occurred after 14 years of age.

(4) The pattern of age changes in the relative sitting height was not the same between the hybrids and Japanese. In the negro male hybrids, the relative sitting height was markedly smaller than the white hybrids and the Japanese all over the period from 6 to 15 years of age. Hereditary factors are considered most responsible for this difference.

The authors are indebted to Dr. S. SAKASEGAWA, professor at the Nippon Veterinary and Zootechnical College, for his kind suggestions in preparing the English manuscript.

\title{
REFERENCES
}

SudA, A., B. Yamaguchi, H. Hoshi, B. Endo and M. ETo, 1965: Longitudinal observation on the stature and body weight of Japanese-American hybrids from 6 to 15 years of age. J. Anthrop. Soc. Nippon, 73, 54-63.

Japanese Ministry of Education, 1952 to 1962: Annual Report and Statistics on Health and Welfare of School Children and Students. Government Printing Office, Tokyo (Japanese text).

\author{
1) Faculty of Letters, Keio University, Tokyo \\ 2) Department of Anatomy, Faculty of medicine, \\ University of Tokyo, Tokyo \\ 3) Department of Ergonomics, Ky $\bar{u} s h \bar{u}$ Institute \\ of Design \\ 4) Department of Anatomy, Nippon Medical \\ School, Tokyo \\ 5) Department of Anatomy, Faculty of Medicine, \\ University of Tokyo, Tokyo
}


日米混血児の胸团と坐高の長期観察*

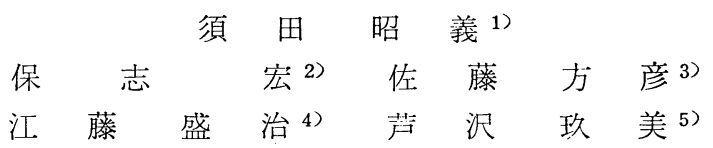

神奈川県大磯町エリザベス・サンダース・ホームに収容されているアメリカ（白・黒）人を父とし，日 本人を母とする混血児についての個人追跡的研究のうち, 生体計測部門の第 2 報である。調査を行つた混 血児は相当数に上るが, 本報告での分析は 6 才から 15 才まで継続観察できた男 36 名, 女 21 名に限つた。乙 れは身長・体重を扱つた第 1 報と完全に同一の被検者である。混血児のうち，父がアメリカ白人である者 (以下 J-W と略す) と, 父がアメリカ黒人である者（以下 $\mathrm{J}-\mathrm{N}$ と略す）とを区別して扱つた。アメリ 力白人あるいは黒人についての，適当な比較資料が入手できなかつたので，日本人との比較にとどめざる を得なかつた。日本人の資料は, 毎年文部省から出されている学校保健統計報告書から, 1947年生れの者 の值を抜き出して用いた。それ故，一般の横断的方法で得たものと異なり，乙の日本人のデータには時代 差は含まれていない。

（1）胸囲の絶対值： J - W と J - N との間には男女とも全く差がなかつた。日本人との差は，男では14 才以後, 女では $\mathrm{J}-\mathrm{W}$ は 7 才以後, $\mathrm{J}-\mathrm{N}$ は 9 才以後, 有意に混血児のほうが大きくなる傾向を示してい る。女の場合は混血児のほうが乳房の発達が良いことも影響しているか屯しれない。

（2）胸囲の年間増加量：身長・体重の場合と全く同じ関係を示した。すなわち，最大増加年令は男で約 1 年混血児がおくれるが女では日本人とほぶ一致すること，最大増加量は混血児が日本人よりはるかに大 きいととである。

（3）坐高の絶対值：男では 12 才以後 $\mathrm{J}-\mathrm{N}$ と J - W との間に有意の差が現われ，前者が小さい。日本人 との差は統計上散発的にみられるのみで，傾向がよくわからない。女では 6 才から15才まで， 3 グループ の間に全く差がみられなかつた。

(4) 坐高の年間増加量：最大増加年令は，男では $J-W$ が約 1 年ほど日本人よりおくれており，女では 反対に $\mathrm{J}-\mathrm{N}$ が約 1 年ほど日本人より早くなつている。最大増加量は, 身長・体重・胸囲の場合と異なつ て, 混血児も日本人と大差を示さない。この不一致は, 前 3 者が個体の全体としての大きさを表わすのに 対して，坐高は部分の大きさを示す数值であるという理由にも関係するかもしれない。

(5) 比胸囲：男では 6 才から 15 才まで 3 者の間に差がない。女では思春期前には $\mathrm{J}-\mathrm{W}>$ 日本人> $\mathrm{J}-\mathrm{N}$ の順であるが，思春期でろから $\mathrm{J}-\mathrm{N}$ が著しくスパートして，14才では $\mathrm{J}-\mathrm{W}=\mathrm{J}-\mathrm{N} 》$ 日本人という関 係になる

(6) 比坐高：男では，6〜15才を通じて J - W と日本人とは差がないが， J - N は著しく低値を示す。 $\mathrm{J}-\mathrm{W}$ と $\mathrm{J}-\mathrm{N}$ との差は各年令とも有意である。乙れは親（アメリカ白・黒人）の体型の反映と思われる。 女では $\mathrm{J}-\mathrm{W}$ がややちがつた傾向を示しているが， 3 者間の差は小さく， J-W と J-N との差はすべて 有意でない。日本人との差も恐らく有意ではなかろうと思われる。
1) 慶応義塾大学文学部
2) 東京大学医学部解剖学教室
3) 九州芸術工科大学人間工学教空
4) 日本医科大学解剖学教室
5) 東京大学医学部解剖学教辤

* 本研究の一部は文部省科学研究費によつた。また本研究の一部は第33回日本解剖学会関東地力会（1966）において報告した。 